\begin{tabular}{|l|l|l|}
\hline \multicolumn{2}{|c|}{ PublisherInfo } \\
\hline \hline PublisherName & $:$ & BioMed Central \\
\hline \hline PublisherLocation & $:$ & London \\
\hline \hline PublisherImprintName & $:$ & BioMed Central \\
\hline \hline
\end{tabular}

\title{
Autoimmune diseases get the NOD
}

\begin{tabular}{|l|l|l||}
\hline \multicolumn{2}{|c|}{ ArticleInfo } \\
\hline \hline ArticleID & $:$ & 3984 \\
\hline \hline ArticleDOI & $:$ & $10.1186 /$ gb-spotlight-20010219-03 \\
\hline \hline ArticleCitationID & $:$ & spotlight-20010219-03 \\
\hline \hline ArticleSequenceNumber & $:$ & 55 \\
\hline \hline ArticleCategory & $:$ & Research news \\
\hline \hline ArticleFirstPage & $:$ & 1 \\
\hline \hline ArticleLastPage & $:$ & 2 \\
\hline \hline & & RegistrationDate : 2001-02-19 \\
ArticleHistory & $:$ & OnlineDate \\
\hline \hline ArticleCopyright & $:$ & BioMed Central Ltd2001 \\
\hline \hline ArticleGrants & $:$ & \\
\hline \hline ArticleContext & $:$ & 130592211 \\
\hline \hline
\end{tabular}




\section{Jonathan B Weitzman}

Email: jonathanweitzman@hotmail.com

Type 1 diabetes (also known as insulin-dependent diabetes mellitus, IDDM) is an autoimmune disease in which the patient's immune system destroys insulin-producing $\beta$ cells of the pancreatic islets of Langerhans. The NOD (non-obese diabetic) mouse has served as a powerful animal model for deciphering the complex genetic contributions to IDDM disease. In the February Nature Genetics, Morahan et al. describe the identification of IDDM18, a new locus associated with human type 1 diabetes, following a hint from studies of NOD mice (Nat Genet 2001, 27:218-221). A search for human homologs of NOD diabetes susceptibility loci led Morahan and colleagues to the human IL12B gene, which encodes a subunit of the interleukin 12 (IL-12) cytokine. They type 249 sibpairs for markers at the IL12B locus on chromosome 5q33-34. HLA-identical pairs showed strong linkage to this region. They identified a polymorphism in the $3^{\prime}$ UTR of IL12Bthat appears to confer susceptibility by altering the levels of IL-12 expression. It is possible that the effect IL-12 has on regulating T-cell responses plays a role in other autoimmune diseases.

\section{References}

1. Insulin-dependent diabetes mellitus as an autoimmune disease.

2. Genetics of autoimmune diabetes in animal models.

3. Nature Genetics, [http://genetics.nature.com]

This PDF file was created after publication. 